2017-06-17

\title{
Solid-Phase Peptide Synthesis of Analogues of the N-Terminus A- ring Fragment of the Lantibiotic Nisin: Replacements for the Dehydroalanine (Dha) Residue at Position 5 and the First Incorporation of a Thioamide Residue
}

\author{
Kim Manzor \\ Institute of Technology Tallaght \\ Keith Ó Proinsias \\ Polish Academy of Sciences, Institute of Organic Chemistry \\ Fintan Kelleher \\ Technological University Dublin, fintan.kelleher@tudublin.ie
}

Follow this and additional works at: https://arrow.tudublin.ie/ittsciart

Part of the Medicinal-Pharmaceutical Chemistry Commons, and the Organic Chemistry Commons

\section{Recommended Citation j.tetlet.2017.06.052 \\ This Article is brought to you for free and open access by the School of Science and Computing at ARROW@TU Dublin. It has been accepted for inclusion in Articles by an authorized administrator of ARROW@TU Dublin. For more information, please contact arrow.admin@tudublin.ie, aisling.coyne@tudublin.ie, gerard.connolly@tudublin.ie. Funder: Science Foundation Ireland}

Manzor, K., O'Proinsias, K. \& Kelleher, F. (2017) Solid-Phase Peptide Synthesis of Analogues of the NTerminus A-ring Fragment of the Lantibiotic Nisin: Replacements for the Dehydroalanine (Dha) Residue at Position 5 and the First Incorporation of a Thioamide Residue, Tetrahedron Letters, DOI: 10.1016/




Solid-phase peptide synthesis of analogues of the N-terminus A-ring fragment of the lantibiotic nisin: Replacements for the dehydroalanine (Dha) residue at position 5 and the first incorporation of a thioamide residue

\author{
Kim Manzor, ${ }^{1}$ Keith ó Proinsias ${ }^{2}$ and Fintan Kelleher ${ }^{1 *}$
}

1. Molecular Design \& Synthesis Group, Centre of Applied Science for Health, Institute of Technology Tallaght, Dublin 24, Ireland

2. Polish Academy of Sciences, Institute of Organic Chemistry, Kasprzaka 44-52, PL-

01224 Warsaw, Poland

Corresponding Author: $\quad$ Fintan Kelleher

Address: Department of Science,

Institute of Technology Tallaght,

Tallaght,

Dublin 24,

Ireland.



e-mail address: $\quad$ fintan.kelleher@ittdublin.ie 


\section{Graphical abstract:}

Solid-phase peptide synthesis of analogues of the $\mathbf{N}$-terminus A-ring fragment of the lantibiotic nisin: Replacements for the dehydroalanine (Dha) residue at position 5 and the first incorporation of a thioamide residue

Kim Manzor, Keith ó Proinsias and Fintan Kelleher*
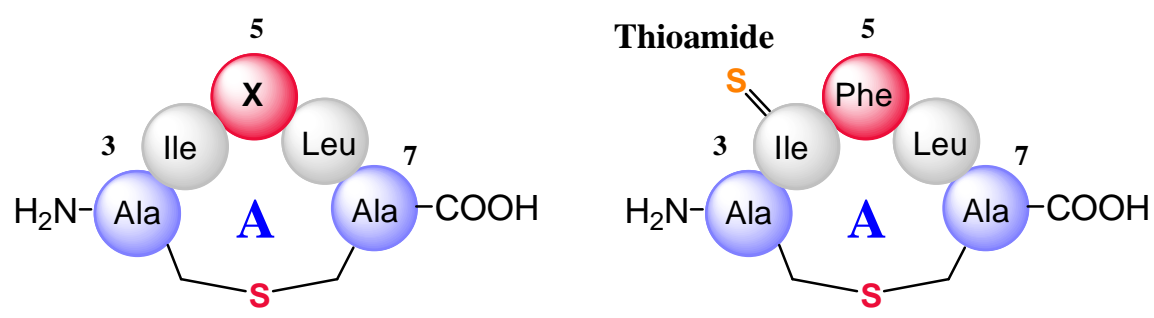

X = Gly, Ala, Phe, Ser, ACCa 


\title{
Solid-phase peptide synthesis of analogues of the N-terminus A-ring fragment of the lantibiotic nisin: Replacements for the dehydroalanine (Dha) residue at position 5 and the first incorporation of a thioamide residue
}

\author{
Kim Manzor, ${ }^{1}$ Keith ó Proinsias ${ }^{2}$ and Fintan Kelleher ${ }^{1 *}$
}

\author{
1. Molecular Design \& Synthesis Group, Centre of Applied Science for Health, Institute of \\ Technology Tallaght, Dublin 24, Ireland \\ 2. Polish Academy of Sciences, Institute of Organic Chemistry, Kasprzaka 44-52, PL- \\ 01224 Warsaw, Poland
}

\begin{abstract}
:
A number of A-ring analogues of the lantibiotic nisin, containing replacements for the Dha at position 5, have been successfully prepared by solid-phase peptide synthesis. The Dha replacements include glycine, alanine, phenylalanine, serine and 1-aminocyclopropyl carboxylic acid (ACCa). The incorporation of a thioamide-isoleucine residue at position 4 is also described and is the first report of the preparation of a lantibiotic ring fragment containing a thioamide link.
\end{abstract}

Keywords: Nisin; thioamide; microwave-enhanced solid-phase peptide synthesis; lantibiotics; dehydroalanine

The lantibiotics are a class of ribosomally synthesised peptides which are subsequently highly post-translationally modified. ${ }^{1}$ They are short peptides, with 19-34 amino acid residues, and contain a number of unusual amino acids within their structures. Rather than being linear peptides they contain a number of small cyclic motifs within their overall structures formed by thioether linkages, as compared to the more common disulfide linkages. The best known, and most studied, lantibiotic is nisin, which has been used as a food preservative (E234) for over 50 years without the development of significant antimicrobial resistance. It is produced by a Lactococcus lactis species and is highly active against a wide-range of Gram-positive bacterial species including MRSA and the food- 
borne pathogen Listeria monocytogenes. It is a 34 amino acid residue peptide with five internal rings (A-E) within its overall sequence (Figure 1).

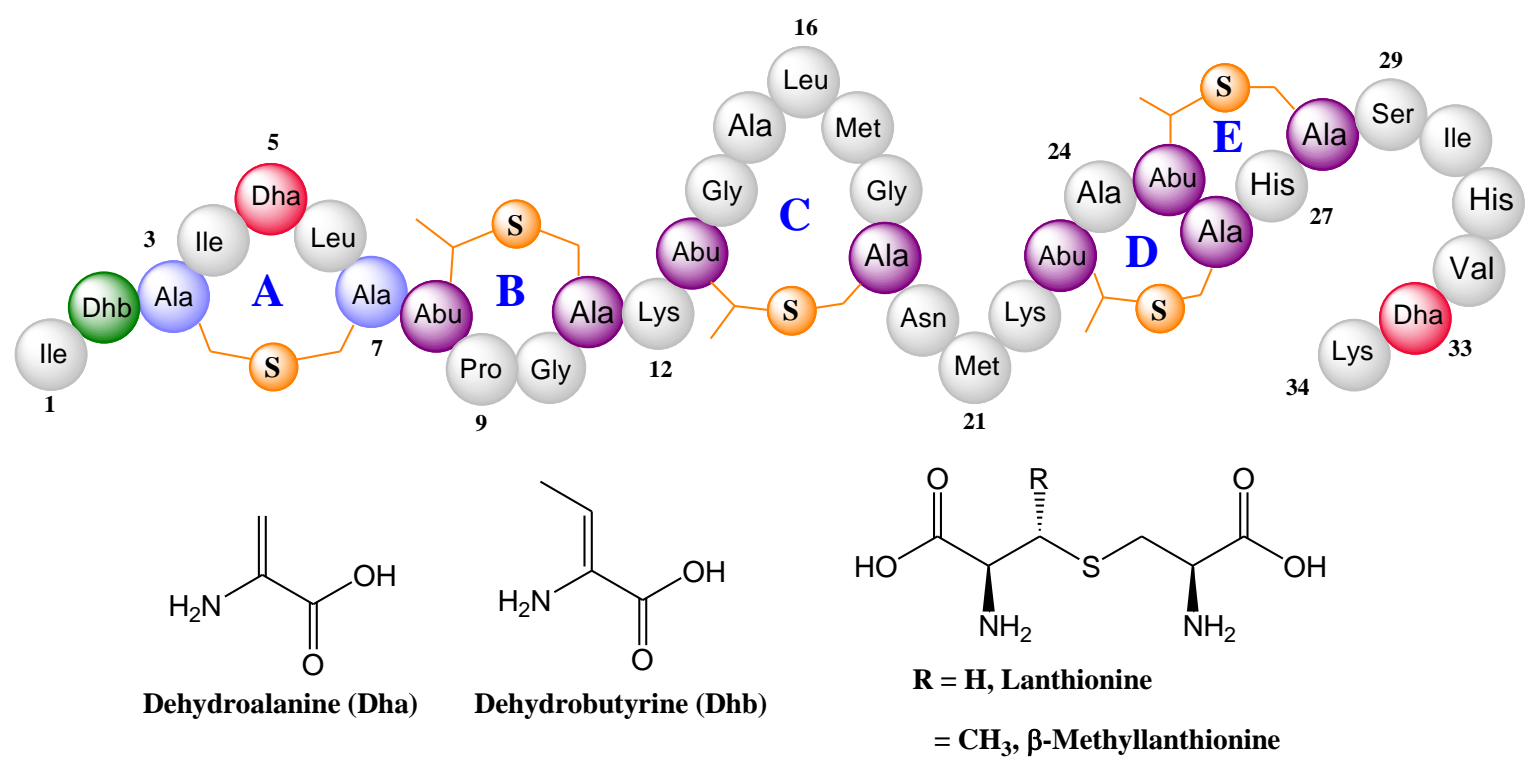

Figure 1. The amino acid sequence of nisin $\mathrm{A}$ and the structures of its unusual amino acid residues

The unusual amino acids present in nisin are dehydroalanine (Dha), dehydrobutyrine (Dhb), lanthionine and $\beta$-methyllanthionine. Of the 34 amino acids of nisin 13 are unusual, which along with the fact that there are no aromatic amino acid residues present makes the overall structure of nisin unique. The A-ring contains a lanthionine bridge (Ala-S-Ala) while the remaining $\mathrm{B}-\mathrm{E}$ rings contain $\beta$-methyllanthionine bridges (Abu-S-Ala). Nisin is both stable and soluble at acidic $\mathrm{pH}$ values having its maximum stability at $\mathrm{pH} 3-4{ }^{2}$ However, its stability and solubility decrease considerably at physiological $\mathrm{pH}$ which precludes its use as a human therapeutic. The A and $\mathrm{B}$ rings of the $\mathrm{N}$-terminus of nisin $\left(\right.$ nisin $\left._{3-12}\right)$ are critical to its overall biological activity where it binds to the lipid II moiety inhibiting the biosynthesis of the bacterial cell wall. ${ }^{3}$ It is known that at physiological $\mathrm{pH}$ the two Dha residues at positions 5 and 33 are cleaved by hydrolysis. ${ }^{4}$ In particular hydrolysis of Dha5 leads to opening of the A-ring which abolishes its biological activity, while cleavage at Dha33 alone leads to a small drop in activity. A significant number of structure-activity relationship studies on nisin involving mutagenesis have been undertaken which show that it is possible to replace Dha5 while retaining activity. ${ }^{5}$ However, little is known about how such amino acid mutations change the overall 3-D conformation of the critical N-terminus region. NMR studies by the Murray group showed that the overall 
conformation of the A-ring of nisin changed substantially when the Dha5 residue was replaced by either a L-Ala or D-Ala moiety. ${ }^{6}$ For our studies one of the crucial aspects of the endeavour would be the synthesis of useful A-ring analogues of nisin, where Dha5 has been replaced, to study how changes affect both the conformations adopted and the resulting stability of the peptides. Herein, the initial synthetic targets, where the replacement of Dha5 with glycine, L-alanine, L-serine and L-phenylalanine residues is described. The reasons for choosing these initial targets of amino acids were that i) glycine would show the effect of removal of all rigidity at position 5; ii) L-alanine was the direct analogue of Dha where the double bond was removed; iii) serine is a precursor to the Dha moiety by dehydration and iv) phenylalanine is present at position 5 in the closely related lantibiotics epidermin and gallidermin, which also bind to lipid II. ${ }^{1}$ A further analogue targeted was the incorporation of a cyclopropyl group, which would require the use of 1aminocyclopropane carboxylic acid (ACCa). Since the Dha5 moiety is cleaved at physiological $\mathrm{pH}$ leading to ring-opening and complete loss of biological activity, it is postulated that the cyclopropyl group would be a more hydrolytically stable mimic of the Dha group, while keeping the overall conformation of the peptide ring. Furthermore, it is known that the group can interact through hyperconjugation with a carbonyl group, in a manner akin to a vinyl group. ${ }^{7}$ The $\mathrm{N}-\mathrm{C}_{\alpha}-\mathrm{C}(=\mathrm{O})$ bond angle of the ACCa is usually close to $116^{\circ},{ }^{6}$ which is closer to the theoretical $120^{\circ}$ of the $\mathrm{sp}^{2}$ hybridised system of the Dha than the tetrahedral bond angle of $109.5^{\circ}$ (Figure 2).

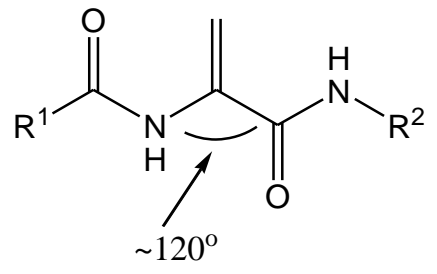

Dehydroalanine

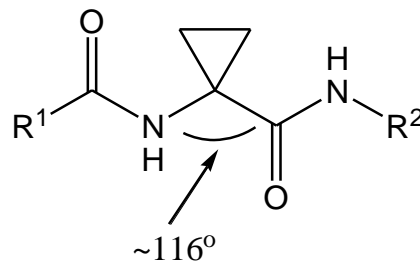

ACCa

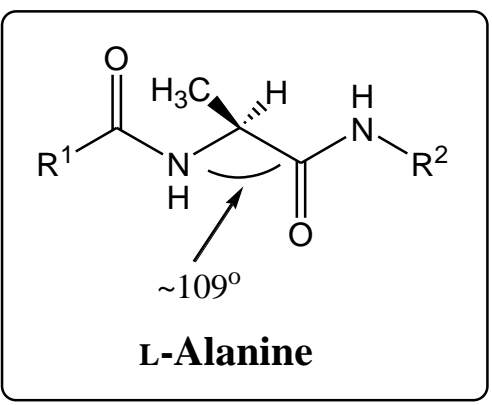

Figure 2. $\mathrm{N}-\mathrm{C}_{\alpha}-\mathrm{C}(=\mathrm{O})$ bond angles for Dha, ACCa and Ala

The proposed Dha5 replacements will ultimately give a greater understanding of how and why structural changes in that region might impact the overall biological activity.

Previously lantibiotics have been prepared by solid-phase peptide synthesis (SPPS), including epilancin $\mathrm{X},{ }^{8}$ lacticin $3147 \mathrm{a}$ and $3147 \mathrm{~b},{ }^{9}$ and Cytolysin. ${ }^{10}$ These syntheses 
required the reliable preparation of significant quantities of orthogonally protected lanthionines and $\beta$-methyllanthionines with tailored protecting groups suitable for SPPS.

\section{Lanthionine Synthesis}

Although a wide number of methods are published for the synthesis of orthogonally protected lanthionines ${ }^{11}$ we found that a variation of the methods described by Schmidt, ${ }^{12}$ and van der Donk, ${ }^{8}$ using phase-transfer catalysis, to be the most reproducible and high yielding. Thus the two coupling partners, bromoalanine $\mathbf{1}$ and cysteine $\mathbf{2}$ were prepared and used immediately due to their instability over time and upon exposure to air. The reaction was conducted in a degassed mixture of ethyl acetate and aqueous sodium hydrogen carbonate in the presence of tetrabutylammonium bromide at $\mathrm{pH}$ 8.5. Wavering from these precise conditions, i.e., not sufficiently degassing the reaction mixture nor maintaining it at exactly $\mathrm{pH} 8.5$, resulted in very low isolated yields of $\mathbf{3}$, due to oxidation of $\mathbf{2}$ to the cystine, and/or the formation of significant amounts of a diastereoisomer of $\mathbf{3}$. Thus, orthogonally protected lanthionine $\mathbf{3}$ was successfully prepared in an isolated yield of 55\% (based on bromoalanine 1) as a single diastereoisomer (Scheme 1). Subsequent deprotection of the $t$-butyl ester gave the desired lanthionine 4, ready for use in SPPS.

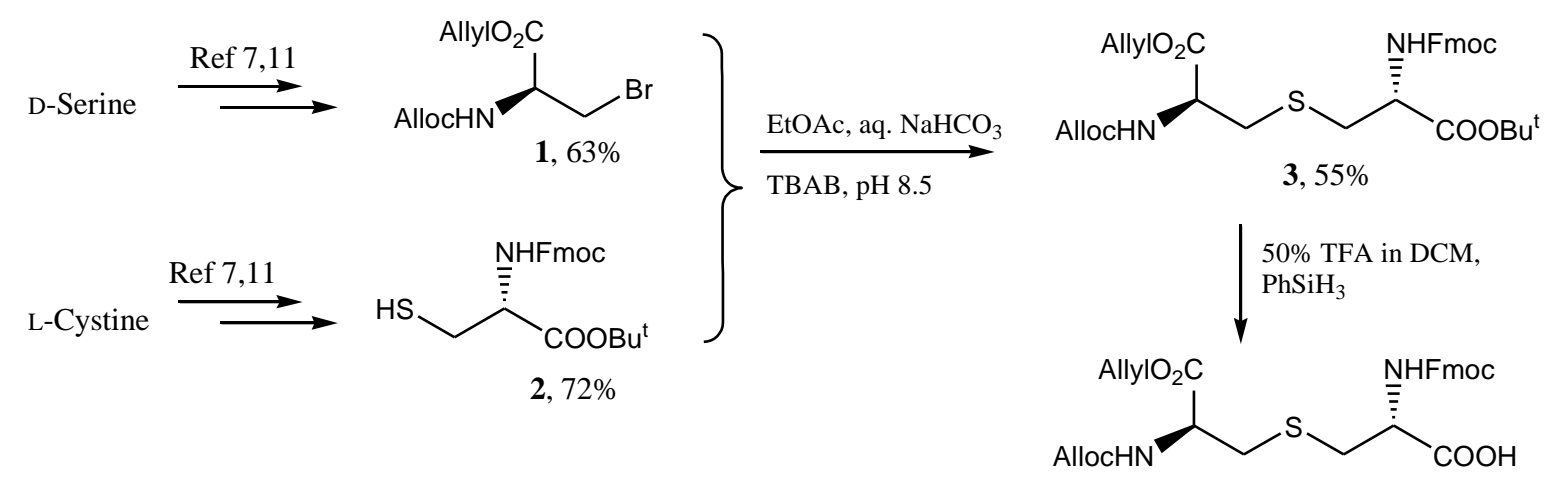

$4,86 \%$

Scheme 1. Synthesis of orthogonally protected lanthionine $\mathbf{4}^{7,11}$

\section{Preparation of the nisin A-ring analogues by SPPS}

Having successfully obtained orthogonally protected lanthionine 4 it was then used for preparation of a number of analogues of the A-ring of nisin by SPPS. The resin chosen for SPPS was a 2-chlorotrityl chloride resin $(1.33 \mathrm{mmol} / \mathrm{g}$ loading $)$ because of its successful use by Vederas for the synthesis of both components of lacticin $3147 .{ }^{9}$ The preparation of the analogue containing a glycine in place of Dha5, i.e. Dha5Gly, is exemplified in Scheme 
2. The other analogues were prepared using similar methodology. Lanthionine 4 was first coupled to the resin to give a reduced loading of $0.16 \mathrm{mmol} / \mathrm{g},{ }^{9}$ with the remaining reactive sites being capped with acetic acid. A Kaiser test showed the absence of free $\mathrm{NH}_{2}$ groups. ${ }^{13}$ The Fmoc group of the resin-loaded lanthionine 5 was efficiently removed using $20 \%$ piperidine in DMF using microwave enhancement at $50{ }^{\circ} \mathrm{C}$ for $10 \mathrm{~min}$. Coupling was undertaken using a pre-activated solution of Fmoc leucine (5 molar equivalents), PyBOP (5 molar equivalents), $\mathrm{HOBt}$ (5 molar equivalents) and $\mathrm{N}$-methylmorpholine (5.5 molar equivalents), using microwave enhancement at $75^{\circ} \mathrm{C}$ for $10 \mathrm{~min}$, to give peptide 6 .
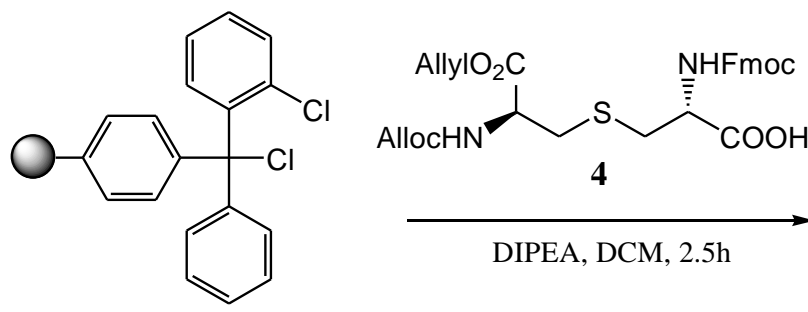

2-Chlorotrityl resin


iii) $20 \%$ piperidine in DMF MW $50^{\circ} \mathrm{C}, 10 \mathrm{~min}$.

iv) $\mathrm{Pd}\left(\mathrm{PPh}_{3}\right)_{4}, \mathrm{PhSiH}_{3}, \mathrm{DCM} / \mathrm{DMF}$

v) $\mathrm{PyBOP}, \mathrm{HOBt}$,

$N$-methylmorpholine, DMF,

MW $75^{\circ} \mathrm{C}, 10 \mathrm{~min}$

vi) TFA:anisole: $\mathrm{H}_{2} \mathrm{O}(95: 5: 5)$

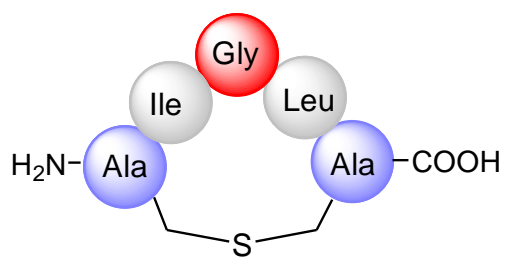

12

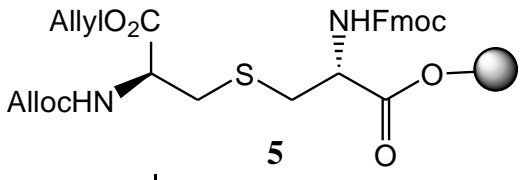

i) $20 \%$ piperidine in $\mathrm{DMF}$ MW $50{ }^{\circ} \mathrm{C}, 10 \mathrm{~min}$.

ii) Fmoc-Leu, PyBOP, HOBt, $\mathrm{N}$-methylmorpholine, DMF, MW $75^{\circ} \mathrm{C}, 10 \mathrm{~min}$
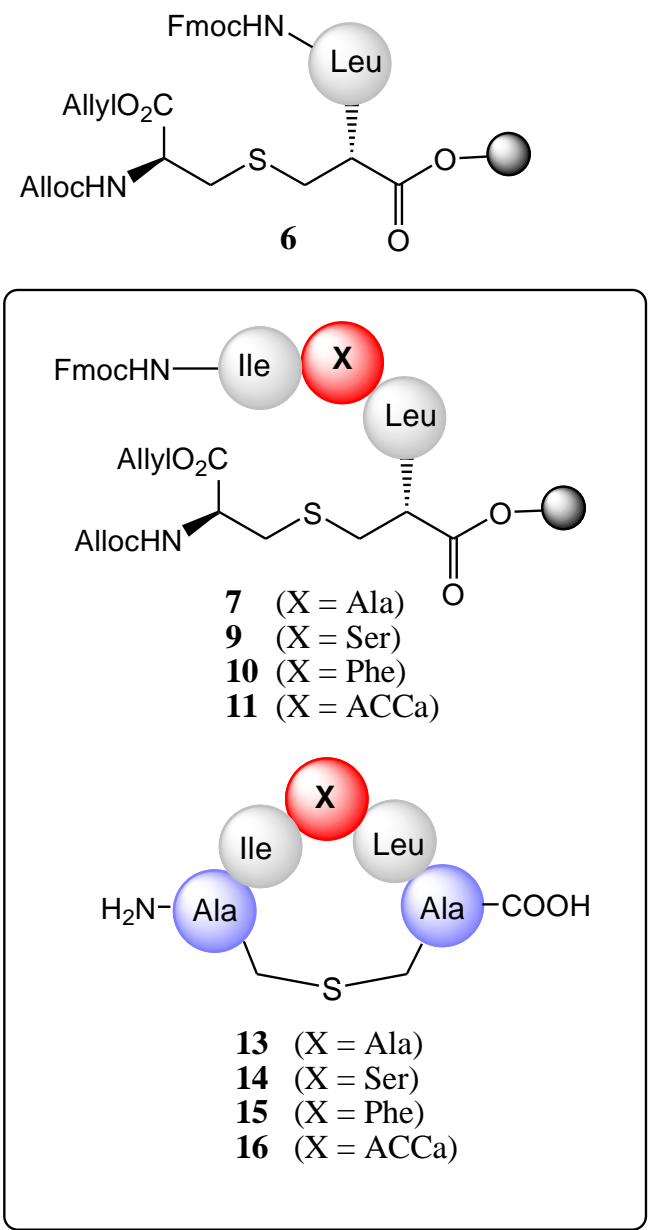

Scheme 2. Synthesis of nisin A-ring analogues (12-16), with position Dha5 modified 
This loaded resin was then split into five equal portions for the synthesis of the target analogues. Separately, Fmoc L-alanine, Fmoc glycine, Fmoc L-serine, Fmoc Lphenylalanine and Fmoc ACCa were successfully coupled using the same coupling protocol, followed by deprotection and the final coupling of Fmoc L-isoleucine to give peptides 7-11. Removal of the two allyl based protecting groups was achieved by treatment with $\mathrm{Pd}\left(\mathrm{PPh}_{3}\right)_{4}$ in $\mathrm{DCM} / \mathrm{DMF}$ (50:50), in the presence of phenylsilane as a scavenger. Subsequent cyclisation on the resin using PyBop (5 molar equivalents), HOBt (5 molar equivalents) and $N$-methylmorpholine (5.5 molar equivalents), using the method of Vederas, ${ }^{14}$ gave the five analogues (12-16) of the nisin A-ring, as confirmed by HRMS analysis after cleavage from the resin using TFA (See Table 1 in Supporting Information).

\section{Incorporation of a thioamide residue at position 4 (isoleucine) of the A-ring of nisin}

As part of its mechanism of action nisin is known to bind to the pyrophosphate moiety of lipid II, which is present in the bacterial cell wall, through five key $\mathrm{H}$-bonding interactions of the N-H protons of the A and B rings. ${ }^{15}$ One of these key interactions involves the N-H of the Dha5 residue of the A-ring.

It is known that thioamides are significantly better $\mathrm{H}$-bond donors than their amide counterparts, ${ }^{16}$ therefore, we envisaged that replacement of Ile4 with thioamide-Ile4 would lead to stronger H-bonding to the pyrophosphate moiety. In order to achieve this goal thioamide dipeptide $\mathbf{1 8}$ must be synthesised followed by incorporation into the A-ring, using methods employed for the amide analogues 12-16. We have recently reported the efficient synthesis of such dipeptides via the selective thionation of the amide group of protected dipeptides, ${ }^{17}$ using Curphey's method. ${ }^{18}$ 



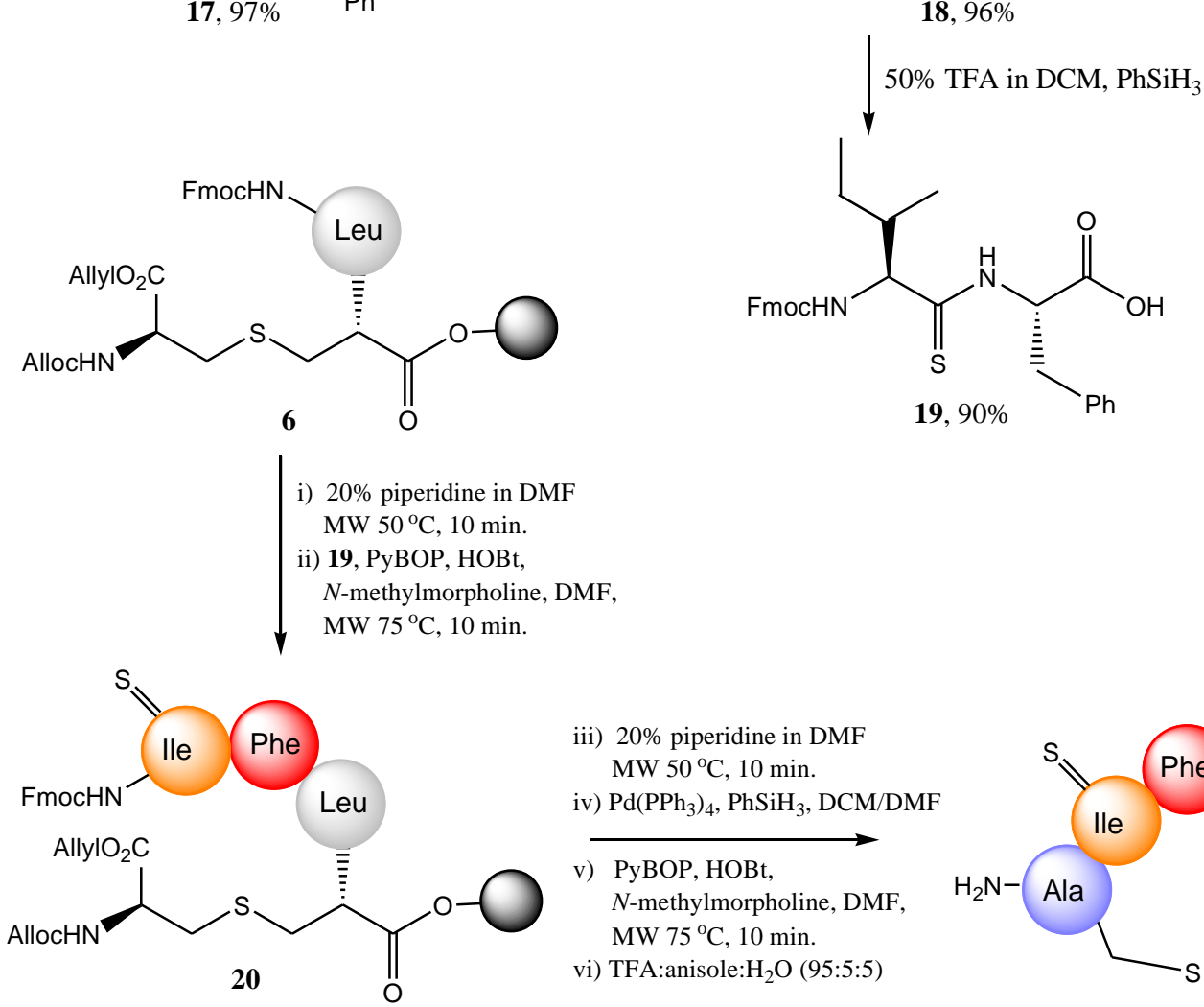

iii) $20 \%$ piperidine in $\mathrm{DMF}$ MW $50{ }^{\circ} \mathrm{C}, 10 \mathrm{~min}$.

iv) $\mathrm{Pd}\left(\mathrm{PPh}_{3}\right)_{4}, \mathrm{PhSiH}_{3}, \mathrm{DCM} / \mathrm{DMF}$

v) PyBOP, HOBt, $N$-methylmorpholine, DMF, MW $75^{\circ} \mathrm{C}, 10 \mathrm{~min}$

vi) TFA:anisole: $\mathrm{H}_{2} \mathrm{O}(95: 5: 5)$

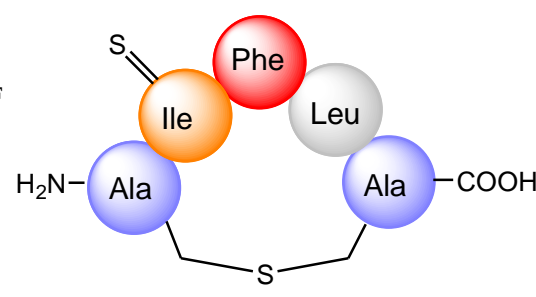

21

Scheme 3. Synthesis of thioamide-Ile4 nisin A-ring analogue 21

Coupling of the deprotected thioamide dipeptide 19 to resin-loaded peptide 6, which had been firstly deprotected with $20 \%$ piperidine in DMF, gave thioamide peptide 20. Subsequent deprotection and cyclisation gave the cyclised peptide $\mathbf{2 1}$ (Table 1). This is the first report of the successful preparation of a lanthionine-containing ring peptide fragment incorporating a thioamide link.

\section{Peptide isolation and purification}

All of the peptides prepared are very hydrophobic in nature and although HRMS analysis of the cleaved product from a small amount of resin showed that the correct cyclic peptides had been formed, there are challenges in the isolation, solubilisation and purification of these peptides. Use of a wide range of published methods for the isolation of hydrophobic peptides, has so far not been fully successful. It is after cyclisation and full cleavage from 
the resin when the solubility problems arise and work is continuing on addressing these issues. However, post cleavage from the resin there is no evidence for any uncyclised peptides remaining by MS analysis, which strongly suggests that cyclisation has

successfully occurred, as seen for other related literature syntheses. ${ }^{8-10,19}$

\section{Conclusions}

For the purpose of investigating the impact of alteration of the reactive Dha5 residue of the A-ring of nisin has on the conformation of the peptide a series of analogues were synthesised on a small scale using SPPS in order to examine and optimise the synthetic route. Firstly, using phase transfer reaction conditions with a suitably protected bromoalanine (1) and cysteine (2) the desired lanthionine 4, a templete for the A-ring, was isolated in 55\% yield, as a single diastereoisomer. Using microwave assisted SPPS a collection of useful A-ring analogues, in which the Dha5 was replaced with Gly, Ala, Ser, Phe or ACCa, were successfully prepared. Furthermore, in order to enhance binding to lipid II, Ile4 of the A-ring was successfully replaced with the significantly better H-bond donor thioamide-Ile4 while incorporating Phe at position 5 in place of Dha. Other thioamide-containing A-ring analogues are now being targeted of the key $\mathrm{H}$-bond donors for the binding interaction with the pyrophosphate moiety of lipid II. ${ }^{15,16}$ Scale-up of the syntheses is currently being undertaken, along with the optimisation of the purification of all the peptides. Detailed NMR studies of all of these peptides will then be undertaken to examine the effects of replacing Dha5 and incorporation of thioamide moieties on the solution conformations. The results of these studies will be reported in due course.

\section{Acknowledgements}

We are grateful to Science Foundation Ireland for funding for KM (Grant number 11/RFP.1/CHS/3306) and to Cycle III of the Higher Education Authority's Program for Research in Third Level Institutions (PRTLI) under the Irish Government's National Development Plan (2000-2006) for funding for K ó P.

\section{Supplementary Data}

Details of the synthesis of compounds 1-4 and 17-19 are described.

\section{References and Notes}


1. a) Dischinger, J.; Chipalu, S. B.; Bierbaum, G. Int. J. Med. Microbiol. 2014, 304, 51; b) Knerr, P. J.; Van der Donk, W. A. Annu. Rev. Biochem. 2012, 81, 479; c) AlMahrous, M.; Upton, M. Expert Opin. Drug Discover. 2011, 6, 155; d) Bierbaum, G.; Sahl, H-G.; Curr. Pharm. Biotech. 2009, 10, 2; e) Willey, J.; Van der Donk, W. A. Annu. Rev. Microbiol. 2007, 61, 477; f) Chatterjee, C.; Paul, M.; Xie, L.; Van der Donk, W. A. Chem. Rev. 2005, 105, 633.

2. Rollema, H.; Kuipers, O.; Both, P.; De Vos, W.; Siezen, R. Appl. Environ. Microbiol. 1995, 61, 2873.

3. Ref. 1. and a) Suganthi, V.; Selvarajan, E.; Subathravedi, C.; Mohanasrinivisan, V. Int. J. Res. Pharmacy 2012, 3, 13. b) Lubelski, J.; Rink, R.; Khusainov, R.; Moll, G.; Kuipers, O. Cell. Mol. Life Sci. 2008, 65, 455.

4. Chan, W.; Dodd, H.; Horn, N.; Maclean, K.; Lian, L-Y.; Bycroft, B.; Gasson, M.; Roberts, G. Appl. Environ. Microbiol. 1999, 62, 2966.

5. Rink, R.; Wierenga, J.; Kuipers, A.; Kluskens, L.; Driessen, A.; Kuipers, O.; Moll, G. Appl. Environ. Microbiol. 2007, 73, 5809.

6. Palmer, D. E.; Pattaroni, C.; Nunami, K.; Chadha, R. K.; Goodman, M.; Wakamiya, T.; Fukase, K.; Horimoto, S.; Kitazawa, M.; Fujita, H.; Kubo, A.; Shiba, T. J. Am. Chem. Soc. 1992, 114, 5634.

7. a) Brackmann, F.; de Meijere, A. Chem. Rev. 2007, 107, 4493; b) Wood, M.; Schirripa, K.; Kim, J.; Wan, B-L.; Murphy, K.; Ransom, R.; Chang, R.; Tang, C.; Prueksaritanont, T.; Detwiler, T.; Hettrick, L.; Landid, E.; Leonard, Y.; Krueger, J.; Lewis, S.; Pettibone, D.; Freidinger, R.; Bock, M. J. Med. Chem. 2006, 49, 1231.

8. Knerr, P. J.; Van der Donk, W. A. J. Am. Chem. Soc. 2012, 134, 7648.

9. Liu, W.; Chan, A.; Liu, H.; Cochrane, S.; Vederas, J. J. Am. Chem. Soc. 2011, 133, 14216.

10. Mukherjee, S.; Huo, L.; Thibodeaux, G.; Van der Donk, W. A. Org. Lett. 2016, 18, 6188.

11. a) Tabor, A. Org. Biomol. Chem. 2011, 9, 7606; b) Martin, N. I. J. Org. Chem. 2009, 74, 946; c) Cobb, S. L.; Vederas, J. C. Org. Biomol. Chem. 2007, 5, 1031.

12. Zhu, X., Schmidt, R. Eur. J. Org. Chem. 2003, 4069.

13. Wellings, D. A.; Atherton, E., Methods Enzymol. 1998, 289, 44.

14. Ross, A.; Liu, H.; Pattabiraman, V.; Vederas, J. J. Am. Chem. Soc. 2010, 132, 462.

15. Hsu, S. T.; Breukink, E.; Tischenko, E.; Lutters, M.; de Kruijff, B.; Kaptein, R.; Bonvin, A.; van Nuland, N., Nat. Struct. Mol. Biol., 2004, 11, 963. 
16. Lee, H-J.; Choi, Y-S.; Lee, K-B.; Park, J.; Yoon, C-J. J. Phys. Chem. A 2002, 106, 7010.

17. Manzor, K.; Kelleher, F. Tetrahedron Lett. 2016, 57, 5237.

18. Curphey, T. J. Org. Chem. 2002, 67, 6461.

19. a) Ross, A.; McKinnie, S.; Vederas, J. J. Am. Chem. Soc. 2012, 134, 2008; b) Mothia, B.; Appleyard, A.; Wadman, S.; Tabor, A. Org. Lett. 2011, 13, 4216; c) Pattabiraman, V.; McKinnie, S.; Vederas, J. Angew. Chem. Int. Ed. 2008, 47, 9472.

\section{Supporting Information}

Solid-phase peptide synthesis of analogues of the N-terminus A-ring fragment of the lantibiotic nisin: Replacements for the dehydroalanine (Dha) residue at position 5 and the first incorporation of a thioamide residue

$$
\text { Kim Manzor, }{ }^{1} \text { Keith ó Proinsias }{ }^{2} \text { and Fintan Kelleher }{ }^{1^{*}}
$$

1. Molecular Design \& Synthesis Group, Centre of Applied Science for Health, Institute of Technology Tallaght, Dublin 24, Ireland.

2. Polish Academy of Sciences, Institute of Organic Chemistry, Kasprzaka 44-52, PL01224 Warsaw, Poland

\section{Experimental Methods}

\section{General Methodology}

IR spectra were recorded on a Nicolet Impact 410 FT-IR and characteristic stretches are reported. Solid samples were prepared as dispersions in $\mathrm{KBr}$ discs and liquid samples as a film between sodium chloride plates. NMR spectra were obtained on a Bruker Avance III 300 spectrometer operating at $300 \mathrm{MHz}$ for ${ }^{1} \mathrm{H}$ spectra. The typical resolution of this machine is $0.095 \mathrm{~Hz}$ or $0.000315 \mathrm{ppm}$, while coupling constant $(J)$ values are accurate to \pm $0.19 \mathrm{~Hz}$. For ${ }^{13} \mathrm{C}$ spectra it operates at $75 \mathrm{MHz}$, with a typical resolution of $0.28 \mathrm{~Hz}$ or 
0.0037 ppm. NMR spectra were also obtained on a Bruker Avance III 500 spectrometer operating at $500 \mathrm{MHz}$ for ${ }^{1} \mathrm{H}$ NMR. The typical resolution of this machine is $0.11 \mathrm{~Hz}$ or $0.00022 \mathrm{ppm}$, while coupling constant $(J)$ values are accurate to $\pm 0.22 \mathrm{~Hz}$. For ${ }^{13} \mathrm{C}$ spectra it operates at $125 \mathrm{MHz}$, with a typical resolution of $0.45 \mathrm{~Hz}$ or $0.0036 \mathrm{ppm}$. The $300 \mathrm{MHz}$ spectrometer was used unless otherwise stated. ${ }^{1} \mathrm{H}$ NMR and ${ }^{13} \mathrm{C}$ NMR assignments were achieved with the aid of the following: DEPT (90 and 135), COSY, HSQC, and HMBC. All solvents used were purchased from Sigma Aldrich or Lennox Chemicals. Solvents were dried and stored in accordance with literature procedures. ${ }^{1}$ Petroleum ether 40-60 was used for all synthesis and purification methods. High Resolution Mass Spectrometry was performed on an Agilent Technologies 6530 Accurate-Mass Q-TOF LC/MS, utilising the Mass-Hunter workstation software. Samples were dissolved in HPLC grade acetonitrile, with volumes injected onto the system of between $0.5-2.0 \mu \mathrm{L}$. The mobile phase (all HPLC grade) used was acetonitrile (70\%), water (30\%), and formic acid (0.1\%). A flowrate of $0.5 \mathrm{~mL} / \mathrm{min}$ of mobile phase was used, while the column in the LC component was a C18 column. UV analysis was performed using a Hitachi U-2900 double beam spectrophotometer. Thin layer chromatography was performed using Merck aluminiumbacked sheets with silica gel 60 F254. Isolated products were purified using flash chromatography with silica gel $(0.040-0.0063 \mathrm{~mm}, 230-400 \mathrm{mesh})$ obtained from VWR. Polarimetry was carried out at room temperature using a $1 \mathrm{dm}$ optical activity tube and an AA-55 Optical Activity Ltd. Polarimeter. Microwave synthesis was conducted using a CEM Focused Microwave Synthesis System, using a Discover SPS manual microwave peptide synthesiser attachment which included a $25 \mathrm{~mL}$ reaction vessel, a reaction vessel holder, a vacuum manifold, and a fiber-optic temperature probe. The manifold consists of two separate fluid paths for both waste and product collection under vacuum.

\section{General Synthetic Methods}

\section{General procedure for coupling using Fmoc solid-phase peptide synthesis (SPPS)}

A coupling solution of Fmoc-protected amino acid (5 molar equivalents to resin loading), HOBT (5 molar equivalents), PyBOP (5 molar equivalents) and $N$-methylmorpholine (5.5 molar equivalents) in DMF was prepared and allowed to pre-activate for $5 \mathrm{~min}$. The solution was transferred to the peptide reaction vessel containing pre-swelled resin (DCM for $30 \mathrm{~min}$.). The reaction vessel was placed in the microwave reactor and heated to $75{ }^{\circ} \mathrm{C}$ $(50 \mathrm{~W})$ for $10 \mathrm{~min}$. The reaction vessel was then cooled to room temperature and was 
shaken for a further 20 min., while nitrogen was gently bubbled through the solution. The resin was washed with DMF (3 x $10 \mathrm{~mL})$ and DCM (3 x $10 \mathrm{~mL})$. A small sample of resin was taken after each coupling step and the peptide was cleaved from the resin (see below) and analysed by LC-MS.

\section{General procedure for peptide cleavage from the resin}

A small sample of resin was taken and peptide cleavage was achieved by treatment with TFA:anisole: $\mathrm{H}_{2} \mathrm{O}$ (95:5:5) and shaking for $1 \mathrm{~h}$, without microwave assistance. The resin was removed by filtration and the filtrate was concentrated in vacuo. The resulting residue was dissolved in acetonitrile and analysed by HRMS to determine the content.

\section{General procedure for Fmoc deprotection}

The $\mathrm{N}$-terminal Fmoc protecting group was deprotected by the addition of $20 \%$ piperidine in DMF $(10 \mathrm{~mL})$ to the peptide reaction vessel. The reaction vessel was placed in the microwave reactor and heated to $50{ }^{\circ} \mathrm{C}(25 \mathrm{~W})$ for $10 \mathrm{~min}$. The resin was cooled to room temperature and washed with DMF (3 x $10 \mathrm{~mL})$ and DCM $(3 \times 10 \mathrm{~mL})$. The deprotection filtrate solution was taken and analysed by UV spectrophotometry, where the presence of the dibenzofulvene-piperidine adduct at $301 \mathrm{~nm}$ determined if the deprotection step was successful.

\section{General procedure for the removal of a $t$-butyl ester group}

To the protected compound $(1.0 \mathrm{mmol})$ was added DCM $(5 \mathrm{~mL})$, TFA $(5 \mathrm{~mL})$, and phenylsilane $(0.13 \mathrm{~mL}, 0.11 \mathrm{~g}, 1.1 \mathrm{mmol})$ and the reaction was stirred for $2 \mathrm{~h}$ in an icebath, under a nitrogen atmosphere. The reaction was monitored by MS until the molecular ion peak of the starter was no longer present. The reaction mixture was then concentrated in vacuo and repeatedly redissolved in DCM and concentrated in vacuo to remove residual TFA.

\section{Syntheses}

Synthesis of allyl (S)-(1-[(allyloxy)carbonyl)]-N-(2-bromoethyl)carbamate (1). D-Serine $(1.00 \mathrm{~g}, 9.51 \mathrm{mmol})$ and $\mathrm{Na}_{2} \mathrm{CO}_{3}(1.05 \mathrm{~g}, 9.90 \mathrm{mmol})$ were dissolved in water $(10 \mathrm{~mL})$ and acetonitrile $(5 \mathrm{~mL})$ was added followed by the dropwise addition of allyl chloroformate 
(1.05 mL, $1.19 \mathrm{~g}, 9.88 \mathrm{mmol}$ ) over $5 \mathrm{~min}$. The mixture was stirred for $30 \mathrm{~h}$, at room temperature, before being concentrated to dryness in vасио. The residue was then dissolved in dry DMF $(20 \mathrm{~mL})$ and $\mathrm{NaHCO}_{3}(0.82 \mathrm{~g}, 9.8 \mathrm{mmol})$ was added followed by the dropwise addition of allyl bromide $(0.85 \mathrm{~mL}, 1.19 \mathrm{~g}, 9.8 \mathrm{mmol})$ over $5 \mathrm{~min}$. The mixture was stirred for $45 \mathrm{~h}$ at room temperature and then concentrated in vacuo. The residue was dissolved in ethyl acetate $(50 \mathrm{~mL})$ and washed with a saturated aqueous $\mathrm{NaHCO}_{3}$ solution $(40 \mathrm{~mL})$, water $(3 \times 40 \mathrm{~mL})$, and brine $(2 \times 30 \mathrm{~mL})$. The organic layer was dried over anhydrous $\mathrm{MgSO}_{4}$ and concentrated in vacuo to afford a yellow oil. Purification by flash chromatography on silica in petroleum ether:ethyl acetate (3:2) gave allyl $(R)-1-[($ allyloxy)carbonyl)]- $N$-(2-hydroxyethyl)carbamate as a pale yellow oil (1.52 $\mathrm{g}$, 70\%). $[\alpha]_{20}^{\mathrm{D}}$ : $+2.96\left(c=1.35\right.$ in $\left.\mathrm{CHCl}_{3}\right) ; \mathrm{R}_{\mathrm{f}}$ 0.56, petroleum ether:ethyl acetate $(2: 1) ;{ }^{1} \mathrm{H}$ NMR $\left(\mathrm{CDCl}_{3}\right) \delta / \mathrm{ppm} ; 6.21(\mathrm{~d}, 1 \mathrm{H}, J=8.3 \mathrm{~Hz}), 5.94-5.86(\mathrm{~m}, 2 \mathrm{H}), 5.25-5.19(\mathrm{~m}, 4 \mathrm{H})$, 4.67-4.64 (m, 4H), 4.44-4.41 (m, 1H), $3.98(\mathrm{dd}, 1 \mathrm{H} J=11.5$ and $3.7 \mathrm{~Hz}), 3.86(\mathrm{dd}, 1 \mathrm{H} J=$ 11.5 and $3.4 \mathrm{~Hz}) ;{ }^{13} \mathrm{C} \mathrm{NMR}\left(\mathrm{CDCl}_{3}\right) \delta / \mathrm{ppm} ; 163.1,156.2,132.5,131.5,118.4,117.6,66.4$, 65.8, 62.6, 56.1; IR (Thin Film, NaCl)/ $\mathrm{cm}^{-1}$; 3404, 2949, 1722, 1689, 1645, 1320; HRMS: $\mathrm{ES}^{+}$for $\mathrm{C}_{10} \mathrm{H}_{15} \mathrm{NO}_{5}$, expected $[\mathrm{M}+\mathrm{H}]^{+} 230.1028$, observed $[\mathrm{M}+\mathrm{H}]^{+} 230.1024$.

To a solution of allyl $(R)-1-[($ allyloxy)carbonyl)]- $N$-(2-hydroxyethyl)carbamate $(0.50 \mathrm{~g}$, $2.2 \mathrm{mmol})$ and $\mathrm{CBr}_{4}(1.24 \mathrm{~g}, 3.7 \mathrm{mmol})$ in dry $\mathrm{DCM}(5 \mathrm{~mL})$ at $0{ }^{\circ} \mathrm{C}$ was added $\mathrm{PPh}_{3}(1.17$ $\mathrm{g}, 4.44 \mathrm{mmol}$ ) portionwise over a $5 \mathrm{~min}$ period. The mixture was then stirred at room temperature for $2.5 \mathrm{hr}$, after which it was concentrated in vacuo. Purification by flash chromatography on silica gel in petroleum ether:ethyl acetate (4:1) gave $\mathbf{1}$ as a clear oil $(0.40 \mathrm{~g}, 63 \%) . \mathrm{R}_{\mathrm{f}} 0.75$, petroleum ether:ethyl acetate $(2: 1) ;{ }^{1} \mathrm{H} \mathrm{NMR}\left(\mathrm{CDCl}_{3}\right) \delta / \mathrm{ppm} ; 5.95$ $5.82(\mathrm{~m}, 2 \mathrm{H}), 5.35-5.17(\mathrm{~m}, 4 \mathrm{H}), 4.81-4.75(\mathrm{~m}, 1 \mathrm{H}), 4.68-4.55(\mathrm{~m}, 4 \mathrm{H}), 3.79(\mathrm{dd}, 1 \mathrm{H}, J=$ 10.6 and $3.4 \mathrm{~Hz}), 3.68(\mathrm{dd}, 1 \mathrm{H}, J=10.6$ and $3.5 \mathrm{~Hz}) ;{ }^{13} \mathrm{C} \mathrm{NMR}\left(\mathrm{CDCl}_{3}\right) \delta / \mathrm{ppm} ; 163.5$, 152.9, 132.2, 131.3, 118.9, 118.3, 67.0, 66.5, 65.0, 60.8; IR (Thin film, NaCl)/cm ${ }^{-1} ; 3338$, 2947, 1724, 1649, 1519, 1333, 665; HRMS: $\mathrm{ES}^{+}$for $\mathrm{C}_{10} \mathrm{H}_{14} \mathrm{NO}_{4} \mathrm{Br}$, expected $[\mathrm{M}+\mathrm{Na}]^{+}$ 314.0001, observed [M+Na] $]^{+} 314.0003$.

Synthesis of N-(9H-fluorenylmethyloxycarbonyl)-(R)-cysteine t-butyl ester (2). Tributylphosphine $(0.50 \mathrm{~mL}, 0.41 \mathrm{~g}, 2.0 \mathrm{mmol})$ was added to a solution of $N-(9 \mathrm{H}$ fluorenylmethyloxycarbonyl)-(R)-cystine t-butyl ester ${ }^{2}(1.50 \mathrm{~g}, 1.88 \mathrm{mmol})$ in THF (20 $\mathrm{mL}$ ) under a nitrogen atmosphere and the solution was stirred for $15 \mathrm{~min}$. Water $(2.0 \mathrm{~mL})$ was added and the reaction was stirred for an additional $2.5 \mathrm{~h}$. The reaction was 
concentrated in vacuo yielding 2 as a clear oil (1.09 $\mathrm{g}, 72 \%)$. The product was used immediately after preparation due to its instability. ${ }^{1} \mathrm{H}$ NMR $\left(\mathrm{CDCl}_{3}\right) \delta / \mathrm{ppm} ; 7.72(\mathrm{~d}, 2 \mathrm{H}$, $J=7.5 \mathrm{~Hz}), 7.53(\mathrm{~d}, 2 \mathrm{H}, J=7.5 \mathrm{~Hz}), 7.40(\mathrm{dd}, 2 \mathrm{H}, J=7.3$ and $7.5 \mathrm{~Hz}), 7.29(\mathrm{dd}, 2 \mathrm{H}, J=$ 6.9 and $7.3 \mathrm{~Hz}), 5.70(\mathrm{~d}, 1 \mathrm{H}, J=7.4 \mathrm{~Hz}), 4.55-4.45(\mathrm{~m}, 1 \mathrm{H}), 4.58-4.33(\mathrm{~m}, 2 \mathrm{H}), 4.20(\mathrm{dd}$, $1 \mathrm{H}, J=8.9$ and $6.5 \mathrm{~Hz}$ ), 3.03-2.93 (m, 2H), 1.48 (s, 9H); IR (Thin Film, $\mathrm{NaCl}$ ) cm ${ }^{-1}$; 3334, 3064, 2978, 2570 (S-H), 1731, 1605.

Synthesis of 3-[2-(R)-allyloxycarbonyl-2-allyloxycarbonylamino-ethylsulfanyl]-2-(S)-(9Hfluorenylmethyloxycarbonylamino)propionic acid t-butyl ester (3). Cysteine 2 (1.06 g, 2.7 mmol) and $\beta$-bromoalanine 1 (0.82 g, $2.8 \mathrm{mmol})$ were both dissolved in degassed ethyl acetate $(15 \mathrm{~mL})$, under a nitrogen atmosphere. A solution of tetrabutylammonium bromide $(3.55 \mathrm{~g}, 10.0 \mathrm{mmol})$ dissolved in a saturated aqueous $\mathrm{NaHCO}_{3}$ solution $(15 \mathrm{~mL}, \mathrm{pH} 8.5)$ was then added to the mixture, which was stirred vigorously for $18 \mathrm{~h}$ (both the ethyl acetate and $\mathrm{NaHCO}_{3}$ solution were deoxygenated by bubbling nitrogen gas into each solution for $30 \mathrm{~min})$. Ethyl acetate $(15 \mathrm{~mL})$ and $\mathrm{H}_{2} \mathrm{O}(15 \mathrm{~mL})$ were added to the mixture and the organic layer was separated, dried over anhydrous $\mathrm{MgSO}_{4}$ and concentrated in vасио. Purification by flash chromatography on silica gel in petroleum ether: ethyl acetate (4:1) gave 3 as a clear oil $(0.89 \mathrm{~g}, 55 \%)$. $[\alpha]_{20}^{\mathrm{D}}$ : $-6.25\left(c=0.32\right.$ in $\left.\mathrm{CHCl}_{3}\right) ; \mathrm{R}_{\mathrm{f}}$ 0.28, 3:1 petroleum ether:ethyl acetate; ${ }^{1} \mathrm{H} \mathrm{NMR}\left(\mathrm{CDCl}_{3}\right) \delta / \mathrm{ppm} ; 7.72(\mathrm{~d}, 2 \mathrm{H}, J=7.4 \mathrm{~Hz}), 7.63-7.54$ $(\mathrm{m}, 2 \mathrm{H}), 7.39-7.34(\mathrm{~m}, 2 \mathrm{H}), 7.31-7.26(\mathrm{~m}, 2 \mathrm{H}), 5.92-5.79(\mathrm{~m}, 2 \mathrm{H}), 5.77$ (d, 1H, $J=7.5$ $\mathrm{Hz}), 5.69(\mathrm{~d}, 1 \mathrm{H}, J=7.5 \mathrm{~Hz}), 5.31-5.15(\mathrm{~m}, 4 \mathrm{H}), 4.61-4.55(\mathrm{~m}, 4 \mathrm{H}), 4.52-4.46(\mathrm{~m}, 2 \mathrm{H})$, 4.40-4.33 (m, 2H), 4.24-4.19 (m, 1H), 3.07-2.94 (m, 4H), $1.46(\mathrm{~s}, 9 \mathrm{H}) ;{ }^{13} \mathrm{C} \mathrm{NMR}\left(\mathrm{CDCl}_{3}\right)$ $\delta / \mathrm{ppm} ; 170.1$, 169.3, 155.7, 155.6, 143.7, 141.2, 132.2, 131.2, 127.6, 126.9, 125.0, 119.8, 119.0, 117.7, 82.8, 67.1, 66.2, 65.8, 54.6, 53.8, 46.9, 35.7, 35.6, 27.8; IR (Thin Film, $\mathrm{NaCl}) / \mathrm{cm}^{-1}$; 3066, 2948, 1724, 1700, 1536; HRMS: $\mathrm{ES}^{+}$for $\mathrm{C}_{32} \mathrm{H}_{38} \mathrm{~N}_{2} \mathrm{O}_{8} \mathrm{~S}$, expected $[\mathrm{M}+\mathrm{Na}]^{+}$633.2266, observed $[\mathrm{M}+\mathrm{Na}]^{+}$633.2269.

Synthesis of 3-[2-(R)-allyloxycarbonyl-2-allyloxycarbonylamino-ethylsulfanyl]-2-(S)-(9Hfluorenylmethyloxycarbonylamino)propionic acid (4). Lanthionine 3 (0.40 g, $0.66 \mathrm{mmol})$ was deprotected using the general method described. Purification by flash chromatography on silica gel eluting with dichloromethane:methanol (98:2) gave 4 as a pale yellow oil $(0.32 \mathrm{~g}, \quad 86 \%) . \quad[\alpha]_{20}^{\mathrm{D}}: \quad+14.47 \quad\left(c=0.76\right.$ in $\left.\mathrm{CHCl}_{3}\right) ; \quad \mathrm{R}_{\mathrm{f}} \quad 0.19$, dichloromethane:methanol:acetic acid (25:1:0.1); ${ }^{1} \mathrm{H}$ NMR $\left(\mathrm{CDCl}_{3}\right) \delta / \mathrm{ppm} ; 8.93$ (s (br), 
1H), $7.75(\mathrm{~d}, 2 \mathrm{H}, J=7.5 \mathrm{~Hz}), 7.63-7.49(\mathrm{~m}, 2 \mathrm{H}), 7.42-7.34(\mathrm{~m}, 2 \mathrm{H}), 7.32-7.27(\mathrm{~m}, 2 \mathrm{H})$, $6.03(\mathrm{~d}, 1 \mathrm{H}, J=7.9 \mathrm{~Hz}), 5.96-5.78(\mathrm{~m}, 2 \mathrm{H}), 5.35-5.15(\mathrm{~m}, 4 \mathrm{H}), 4.62-4.56(\mathrm{~m}, 6 \mathrm{H}, J=17.2$ and 5.6 Hz), 4.43-4.31 (m, 2H), 4.25-4.19 (m, 1H), 3.13-2.78 (m, 4H); ${ }^{13} \mathrm{C} \mathrm{NMR}\left(\mathrm{CDCl}_{3}\right)$

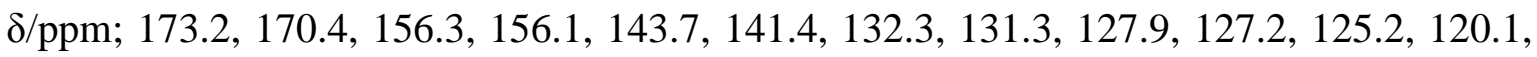
119.5, 118.3, 67.6, 66.7, 66.4, 54.1, 53.7, 47.1, 35.5, 35.4; IR (Thin film, NaCl)/cm ${ }^{-1}$; 3400, 3318, 3051, 2947, 2935, 1725, 1700; HRMS: $\mathrm{ES}^{+}$for $\mathrm{C}_{28} \mathrm{H}_{30} \mathrm{~N}_{2} \mathrm{O}_{8} \mathrm{~S}$, expected $[\mathrm{M}+\mathrm{H}]^{+}$555.1801, observed $[\mathrm{M}+\mathrm{H}]^{+} 555.1796$.

Preparation of lanthionine-loaded resin 5. 2-Chlorotrityl chloride resin (2.0 g, $1.3 \mathrm{mmol} / \mathrm{g}$ loading) was pre-swelled in DCM (20 mL) with gentle shaking for $30 \mathrm{~min}$. A loading solution of orthogonally protected lanthionine $4(0.18 \mathrm{~g}, 0.32 \mathrm{mmol})$ and DIPEA $(0.28 \mathrm{~mL}$, $0.21 \mathrm{~g}, 1.60 \mathrm{mmol})$ in DCM $(20 \mathrm{~mL})$ was added to the resin in a peptide reaction vessel and the mixture was stirred gently for $2.5 \mathrm{~h}$. The solution was filtered from the resin and the resin was then washed with DCM $(3 \times 20 \mathrm{~mL})$. The remaining reactive sites on the resin were then capped using a solution of acetic acid $(0.11 \mathrm{ml}, 0.12 \mathrm{~g}, 2.0 \mathrm{mmol})$ and DIPEA (1.39 ml, $1.03 \mathrm{~g}, 8.00 \mathrm{mmol})$ in DCM (20 mL) for $2 \mathrm{~h}$ with gentle shaking, while $\mathrm{N}_{2}$ was bubbled through the mixture. The resin was washed with DCM (3 x $\left.20 \mathrm{~mL}\right)$. This gave a resin with a reduced loading $(0.16 \mathrm{mmol} / \mathrm{g})$ which was ready for SPPS. The Kaiser test $^{3}$ was carried out on a few resin beads which confirmed there were no primary amines present. A sample of the resin $\mathbf{5}$ was taken and cleaved using the general procedure (see above) and analysed by MS. HRMS: ES+ for $\mathrm{C}_{28} \mathrm{H}_{30} \mathrm{~N}_{2} \mathrm{O}_{8} \mathrm{~S}$, expected $[\mathrm{M}+\mathrm{H}]^{+}$555.1801, observed $[\mathrm{M}+\mathrm{H}]^{+} 555.1808$.

Preparation of Fmoc-Ile-Phe t-butyl ester 17. To an ice-cold slurry of Fmoc-L-isoleucine $(0.71 \mathrm{~g}, 2.0 \mathrm{mmol})$ and and L-phenylalanine $t$-butyl ester $(0.44 \mathrm{~g}, 2.0 \mathrm{mmol})$ in acetonitrile $(10 \mathrm{ml})$ was added $\mathrm{Et}_{3} \mathrm{~N}(0.6 \mathrm{ml}, 0.44 \mathrm{~g}, 4.2 \mathrm{mmol})$ and $\mathrm{HBTU}(0.9 \mathrm{~g}, 2.2 \mathrm{mmol})$ and the reaction mixture was stirred at room temperature for $2 \mathrm{hr}$. The mixture was concentrated under reduced pressure and the residue was taken up in EtOAc and washed with $\mathrm{HCl}(2 \mathrm{M}$, $10 \mathrm{ml}$ ), a saturated aqueous $\mathrm{NaHCO} 3$ solution (10 ml), dried over anhydrous $\mathrm{MgSO} 4$, and concentrated in vacuo. Purification by flash column chromatography on silica gel eluted with petroleum ether:ethyl acetate (4:1) gave $\mathbf{1 7}$ as a white solid (1.08 g, 97\%). $\mathrm{R}_{\mathrm{f}} 0.67$, petroleum ether:ethyl acetate (2:1); M.pt. $136-137^{\circ} \mathrm{C} ;[\alpha]_{\mathrm{D}}^{20}:-20.00\left(c=0.10\right.$ in $\left.\mathrm{CHCl}_{3}\right)$; ${ }^{1} \mathrm{H} \mathrm{NMR}\left(\mathrm{CDCl}_{3}\right) \delta / \mathrm{ppm} ; 7.75(\mathrm{~d}, 2 \mathrm{H}, J=7.4 \mathrm{~Hz}), 7.59$ (d, 2H, $\left.J=7.4 \mathrm{~Hz}\right), 7.42-7.35$ (m, 2H), 7.33-7.27 (m, 2H), 7.24-7.12 (m, 5H), $6.21(\mathrm{~d}, 1 \mathrm{H}, J=7.4 \mathrm{~Hz}), 5.34(\mathrm{~d}, 1 \mathrm{H}, J=8.8$ 
$\mathrm{Hz}), 4.74(\mathrm{dd}, 1 \mathrm{H}, J=7.3$ and $6.2 \mathrm{~Hz}), 4.46-4.35(\mathrm{~m}, 2 \mathrm{H}), 4.26-4.19(\mathrm{~m}, 1 \mathrm{H}), 3.4 .18-4.15$ (m, 1H), $3.07(\mathrm{~d}, 2 \mathrm{H}, J=6.2 \mathrm{~Hz}), 1.88-1.79(\mathrm{~m}, 1 \mathrm{H}), 1.51-1.45(\mathrm{~m}, 1 \mathrm{H}), 1.39(\mathrm{~s}, 9 \mathrm{H})$, 1.18-1.04 (m, 1H), 0.91-0.86 (m, 6H); ${ }^{13} \mathrm{C}$ NMR $\left(\mathrm{CDCl}_{3}\right) \delta / \mathrm{ppm} ; 170.6,170.2,156.2$, 143.9, 141.4, 135.5, 129.5, 128.4, 127.8, 127.2, 127.1, 125.2, 120.0, 82.6, 67.1, 59.7, 53.6, 47.2, 38.2, 37.6, 27.9, 24.8, 15.4, 11.4; IR (KBr)/cm ${ }^{-1}$; 3309 (N-H), 3089 (C-H, aromatic), 2965 (C-H, aliphatic), 1735 ( $\mathrm{C}=\mathrm{O}$, ester $), 1700$ ( $\mathrm{C}=\mathrm{O}$, carbamate), 1655 ( $\mathrm{C}=\mathrm{O}$, amide); HRMS: $\mathrm{ES}^{+}$for $\mathrm{C}_{34} \mathrm{H}_{40} \mathrm{~N}_{2} \mathrm{O}_{5}$, expected $[\mathrm{M}+\mathrm{K}]^{+}$595.2574, observed $[\mathrm{M}+\mathrm{K}]^{+}$595.2571.

Preparation of Fmoc-Ile $(C=S)$-Phe t-butyl ester 18. To a solution of 17 (0.60 g, 1.1 mmol $)$ ) in dry DCM $(20 \mathrm{ml})$ was added $\mathrm{P}_{2} \mathrm{~S}_{5}(0.60 \mathrm{~g}, 1.1 \mathrm{mmol})$ followed by hexamethyldisiloxane (HMDO) $(1.2 \mathrm{ml}, 0.92 \mathrm{~g}, 5.5 \mathrm{mmol})$ and the reaction mixture was stirred at reflux temperature under an atmosphere of nitrogen for $5 \mathrm{hr}$. A further molar equivalent of $\mathrm{P}_{2} \mathrm{~S}_{5}$ and 5 molar equivalents of $\mathrm{HMDO}$ was then added and the mixture was heated at reflux temperature and monitored by TLC until the reaction went to completion. The solution was concentrated in vacuo and the resulting residue was dissolved in EtOAc, washed with water $(2 \times 15 \mathrm{ml})$, brine $(20 \mathrm{ml})$ and dried over anhydrous $\mathrm{MgSO}_{4}$. Purification on silica gel eluting with petroleum ether:ethyl acetate (4:1) gave the desired thioamide as a clear oil $(0.59 \mathrm{~g}, 96 \%) . \mathrm{R}_{\mathrm{f}} 0.81$, petroleum ether:ethyl acetate (2:1); Oil; $[\alpha]_{\mathrm{D}}^{20}:+47.22\left(c=0.36\right.$ in $\left.\mathrm{CHCl}_{3}\right) ;{ }^{1} \mathrm{H} \mathrm{NMR}\left(\mathrm{CDCl}_{3}\right) \delta / \mathrm{ppm} ; 8.35(\mathrm{~d}, 1 \mathrm{H}, J=6.3 \mathrm{~Hz})$, 7.76-7.71 (m, 2H), $7.60(\mathrm{~d}, 2 \mathrm{H}, J=7.3 \mathrm{~Hz}), 7.40-7.34(\mathrm{~m}, 2 \mathrm{H}), 7.32-7.26 \quad(\mathrm{~m}, 2 \mathrm{H})$, 7.24-7.10 (m, 5H), $5.63(\mathrm{~d}, 1 \mathrm{H}, J=8.6 \mathrm{~Hz}), 5.30-5.23(\mathrm{~m}, 1 \mathrm{H}), 4.46-4.28(\mathrm{~m}, 2 \mathrm{H}), \quad 4.26-$ $4.18(\mathrm{~m}, 2 \mathrm{H}), 3.21(\mathrm{~d}, 2 \mathrm{H}, J=6.2 \mathrm{~Hz}), 1.99-1.81(\mathrm{~m}, 1 \mathrm{H}), 1.65-1.53(\mathrm{~m}, 1 \mathrm{H}), 1.37(\mathrm{~s}, 9 \mathrm{H})$, 1.18-1.06 (m, 1H), 0.92-0.85 (m, 6H); ${ }^{13} \mathrm{C}$ NMR $\left(\mathrm{CDCl}_{3}\right) \delta / \mathrm{ppm} ; 204.1,169.5,156.1$, 144.0, 140.4, 135.6, 129.7, 128.6, 127.9, 127.3, 127.3, 125.3, 119.9, 82.2, 67.2, 66.2, 58.9, 47.2, 39.7, 36.6, 28.0, 24.8, 15.8, 11.5; IR (Thin film, NaCl)/cm ${ }^{-1}$; $3276(\mathrm{~N}-\mathrm{H}), 3064$ (C-H, aromatic), 2967, 2933 (C-H, aliphatic), 1728 (C=O, ester), 1693 (C=O, carbamate), 1031 $\left(\mathrm{C}=\mathrm{S}\right.$, thioamide); HRMS: $\mathrm{ES}^{+}$for $\mathrm{C}_{34} \mathrm{H}_{40} \mathrm{~N}_{2} \mathrm{O}_{4} \mathrm{~S}$, expected $[\mathrm{M}+\mathrm{Na}]^{+}$595.2606, observed $[\mathrm{M}+\mathrm{Na}]^{+}$595.2572.

Preparation of Fmoc-Ile $(C=S)$-Phe 19. To $18(0.18 \mathrm{~g}, 0.33 \mathrm{mmol})$ was added DCM (1.5 $\mathrm{ml})$, TFA $(1.5 \mathrm{ml})$, and phenylsilane $(0.04 \mathrm{ml}, 0.033 \mathrm{~g}, 0.33 \mathrm{mmol})$ and the reaction was stirred for $2 \mathrm{hr}$. in an ice-bath, under an atmosphere of nitrogen. The reaction was monitored by LC-MS until the molecular ion peak of the starter was no longer present and this indicated the reaction had gone to completion. The reaction mixture was then 
concentrated in vacuo and repeatedly redissolved in DCM and concentrated in vacuo to remove residual TFA. The product was purified by flash chromatography on silica gel eluting with dichloromethane:methanol (98:2) to yield 19 as a pale yellow oil $(0.16 \mathrm{~g}$, 90\%). $\mathrm{R}_{\mathrm{f}} 0.07$, ethyl acetate:petroleum ether (2:1); ${ }^{1} \mathrm{H}$ NMR $\left(\mathrm{CDCl}_{3}\right) \delta / \mathrm{ppm} ; 8.92(\mathrm{~s}, 1 \mathrm{H})$, $7.76(\mathrm{~d}, 2 \mathrm{H}, J=7.6 \mathrm{~Hz}), 7.51-7.56(\mathrm{~m}, 2 \mathrm{H}), 7.51-7.35(\mathrm{~m}, 2 \mathrm{H}), 7.34-7.28(\mathrm{~m}, 2 \mathrm{H}), 5.87$ (d, $1 \mathrm{H}, J=10.0 \mathrm{~Hz}), 4.89-4.64(\mathrm{~m}, 1 \mathrm{H}), 4.52-4.45$ and 4.35-4.29 (m, 2H), 4.35-4.22 (m, 2H), 4.19-4.13 (m, 1H), 3.75 (s (br), 1H), 1.86-1.75 (m, 1H), 1.72-1.46 (m, 1H), 1.19-1.15 (m, $1 \mathrm{H}), 0.93-0.87(\mathrm{~m}, 6 \mathrm{H}) .{ }^{13} \mathrm{C} \mathrm{NMR}\left(\mathrm{CDCl}_{3}\right) \delta / \mathrm{ppm} ; 204.4,170.9,156.6,143.5,141.3$, 127.8, 127.1, 125.1, 120.1, 67.6, 64.4, 47.3, 47.0, 40.7, 25.2, 15.5, 10.7; IR (KBr)/cm ${ }^{-1}$, 3290 (O-H), 3066 (C-H, aromatic), 2965, 2927 (C-H, aliphatic), 1706 (C=O, acid), 1696 $\left(\mathrm{C}=\mathrm{O}\right.$, carbamate), $908\left(\mathrm{C}=\mathrm{S}\right.$, thioamide); HRMS: $\mathrm{ES}^{+}$for $\mathrm{C}_{23} \mathrm{H}_{26} \mathrm{~N}_{2} \mathrm{O}_{4} \mathrm{~S}$, expected $[\mathrm{M}+\mathrm{H}]^{+}$ 427.1691, observed $[\mathrm{M}+\mathrm{H}]^{+} 427.1702$.

\begin{tabular}{|l|l|l|l|}
\hline Peptide & Molecular Formula & HRMS (Observed) & HRMS (Expected) \\
\hline $\mathbf{4}$ & $\mathrm{C}_{28} \mathrm{H}_{30} \mathrm{~N}_{2} \mathrm{O}_{8} \mathrm{~S}$ & $555.1796[\mathrm{M}+\mathrm{H}]^{+}$ & $555.1801[\mathrm{M}+\mathrm{H}]^{+}$ \\
\hline $\mathbf{7}$ & $\mathrm{C}_{43} \mathrm{H}_{57} \mathrm{~N}_{5} \mathrm{O}_{11} \mathrm{~S}$ & $852.3853[\mathrm{M}+\mathrm{H}]^{+}$ & $852.3829[\mathrm{M}+\mathrm{H}]^{+}$ \\
\hline $\mathbf{8}$ & $\mathrm{C}_{42} \mathrm{H}_{55} \mathrm{~N}_{5} \mathrm{O}_{11} \mathrm{~S}$ & $838.3697[\mathrm{M}+\mathrm{H}]^{+}$ & $838.3692[\mathrm{M}+\mathrm{H}]^{+}$ \\
\hline $\mathbf{9}$ & $\mathrm{C}_{43} \mathrm{H}_{57} \mathrm{~N}_{5} \mathrm{O}_{12} \mathrm{~S}$ & $890.3634[\mathrm{M}+\mathrm{Na}]^{+}$ & $890.3634[\mathrm{M}+\mathrm{Na}]^{+}$ \\
\hline $\mathbf{1 0}$ & $\mathrm{C}_{49} \mathrm{H}_{61} \mathrm{~N}_{5} \mathrm{O}_{11} \mathrm{~S}$ & $928.4166[\mathrm{M}+\mathrm{H}]^{+}$ & $928.4161[\mathrm{M}+\mathrm{H}]^{+}$ \\
\hline $\mathbf{1 1}$ & $\mathrm{C}_{44} \mathrm{H}_{57} \mathrm{~N}_{5} \mathrm{O}_{11} \mathrm{~S}$ & $864.3853[\mathrm{M}+\mathrm{H}]^{+}$ & $864.3850[\mathrm{M}+\mathrm{H}]^{+}$ \\
\hline $\mathbf{1 2}$ & $\mathrm{C}_{20} \mathrm{H}_{35} \mathrm{~N}_{5} \mathrm{O}_{6} \mathrm{~S}$ & $474.2378[\mathrm{M}+\mathrm{H}]^{+}$ & $474.2386[\mathrm{M}+\mathrm{H}]^{+}$ \\
\hline $\mathbf{1 3}$ & $\mathrm{C}_{21} \mathrm{H}_{37} \mathrm{~N}_{5} \mathrm{O}_{6} \mathrm{~S}$ & $488.2545[\mathrm{M}+\mathrm{H}]^{+}$ & $488.2542[\mathrm{M}+\mathrm{H}]^{+}$ \\
\hline $\mathbf{1 4}$ & $\mathrm{C}_{21} \mathrm{H}_{37} \mathrm{~N}_{5} \mathrm{O}_{7} \mathrm{~S}$ & $504.2491[\mathrm{M}+\mathrm{H}]^{+}$ & $504.2508[\mathrm{M}+\mathrm{H}]^{+}$ \\
\hline $\mathbf{1 5}$ & $\mathrm{C}_{27} \mathrm{H}_{41} \mathrm{~N}_{5} \mathrm{O}_{6} \mathrm{~S}$ & $564.2855[\mathrm{M}+\mathrm{H}]^{+}$ & $564.2855[\mathrm{M}+\mathrm{H}]^{+}$ \\
\hline $\mathbf{1 6}$ & $\mathrm{C}_{22} \mathrm{H}_{37} \mathrm{~N}_{5} \mathrm{O}_{6} \mathrm{~S}$ & $500.2542[\mathrm{M}+\mathrm{H}]^{+}$ & $500.2555[\mathrm{M}+\mathrm{H}]^{+}$ \\
\hline $\mathbf{1 7}$ & $\mathrm{C}_{34} \mathrm{H}_{40} \mathrm{~N}_{2} \mathrm{O}_{5}$ & $595.2571[\mathrm{M}+\mathrm{K}]^{+}$ & $595.2574[\mathrm{M}+\mathrm{K}]^{+}$ \\
\hline $\mathbf{1 8}$ & $\mathrm{C}_{34} \mathrm{H}_{40} \mathrm{~N}_{2} \mathrm{O}_{4} \mathrm{~S}$ & $595.2606[\mathrm{M}+\mathrm{Na}]^{+}$ & $595.2572[\mathrm{M}+\mathrm{Na}]^{+}$ \\
\hline $\mathbf{1 9}$ & $\mathrm{C}_{30} \mathrm{H}_{32} \mathrm{~N}_{2} \mathrm{O}_{4} \mathrm{~S}$ & $517.2161[\mathrm{M}+\mathrm{H}]^{+}$ & $517.2169[\mathrm{M}+\mathrm{H}]^{+}$ \\
\hline $\mathbf{2 0}$ & $\mathrm{C}_{49} \mathrm{H}_{61} \mathrm{~N}_{5} \mathrm{O}_{10} \mathrm{~S}_{2}$ & $966.3757[\mathrm{M}+\mathrm{Na}]^{+}$ & $966.3755[\mathrm{M}+\mathrm{Na}]^{+}$ \\
\hline $\mathbf{2 1}$ & $\mathrm{C}_{27} 41_{1} \mathrm{~N}_{5} \mathrm{O}_{15} \mathrm{~S}_{2}$ & $597.2892[\mathrm{M}+\mathrm{NH}]^{+}$ & $597.2874[\mathrm{M}+\mathrm{NH}]^{+}$ \\
\hline
\end{tabular}

Table 1. High-Resolution MS results for all synthesised peptides. 


\section{References}

1. Perrin D. D., Armarego W. L. F., Purification of Laboratory Chemicals, 3rd Ed., Butterworth-Heinemann Ltd., Oxford, United Kingdom, 1988.

2. Mustapa, F.; Harris, R.; Bulic-subanovic, N.; Elliott, S.; Bregant, S.; Groussier, M.; Mould, J.; Schultz, D.; Chubb, N.; Gaffney, P.; Driscoll, C.; Tabor, A., J. Org. Chem., 2003, 68, 8185-8192.

Wellings, D. A.; Atherton, E., Methods Enzymol. 1998, 289, 44-67 